\title{
Information-Seeking Question Intonation in Basque Spanish and Its Correlation with Degree of Contact and Language Attitudes
}

\author{
Magdalena Romera ${ }^{1}$ and Gorka Elordieta ${ }^{2, *(1)}$ \\ 1 Department of Humanities and Education, Public University of Navarre (UPNA), 31006 Pamplona, Spain; \\ magdalena.romera@unavarra.es \\ 2 Department of Linguistics and Basque Studies, University of the Basque Country (UPV/EHU), \\ 01006 Vitoria-Gasteiz, Spain \\ * Correspondence: gorka.elordieta@ehu.eus
}

Received: 18 November 2020; Accepted: 9 December 2020; Published: 14 December 2020

\begin{abstract}
The present study analyzes the prosodic characteristics of the variety of Spanish in contact with Basque (in the Basque Country, Spain). We focus on information-seeking yes/no questions, which present different intonation contours in Spanish and Basque. In Castilian Spanish, these sentences end in a rising contour, whereas in Basque, they end in a falling or rising-falling circumflex contour. In our previous work, this topic was investigated among the urban populations of Bilbao and San Sebastian. The results were that $79 \%$ of information-seeking yes/no questions had final falling intonational configurations. All the speakers presented a substantial presence of final falls regardless of their linguistic profile, but there were differences among speakers in the degree of presence of such features. A correlation was observed between the dependent variable of 'frequency of occurrence of final falls in absolute interrogatives' and social factors, such as 'degree of contact with Basque' and 'attitudes towards Basque and the Basque ethnolinguistic group'. The correlation was that the higher the degree of contact with Basque and the more positive the attitudes towards Basque and the Basque ethnolinguistic group, the greater the frequency of occurrence of final falling intonational contours in information-seeking absolute interrogatives. The interpretation of this correlation was that the adoption of the characteristic Basque prosody allows speakers to be recognized as members of the Basque community. In the present study, we focused on rural areas. Falling intonational contours at the end of information-seeking absolute interrogatives were even more common than in urban areas (93.4\%), and no correlation was found with degree of contact with Basque and with attitudes towards Basque. Our interpretation is that in rural areas the presence of Basque in daily life is stronger, and that there is a consolidated variety of Spanish used by all speakers regardless of their attitudes. Thus, the adoption of intonating features of this language is not the only indicator belonging to the Basque ethnolinguistic group. Our study reveals the great relevance of subjective social factors, such as language attitudes, in the degree of convergence between two languages.
\end{abstract}

Keywords: intonation; language contact; bilingualism; language attitudes; social factors; Spanish; Basque

\section{Introduction}

Within the growing field of research on phonetic and phonological issues of language contact and bilingualism, aspects of suprasegmental phonology have started receiving more attention, especially in prosody and intonation (a comprehensive list of references is provided in Elordieta and Romera (2020a)). A particularly interesting issue is that the presence of features of a language variety (LV-A) in another language variety (LV-B) is variable within the contact population. The main goal of this paper is to show 
that individual social factors of speakers of LV-A may help explain the differences among speakers in the degree of presence of LV-B features. Such factors can be the degree of contact of LV-A speakers with LV-B speakers and the attitudes of LV-A speakers towards LV-B and the LV-B ethnolinguistic group.

Sociolinguistic studies commonly explain linguistic variation in contact situations as the result of two types of factors: internal tendencies of the languages that favor a linguistic change, and the external influence that one language exerts on another in contact situations (Winford 2005, 2014; Poplack and Levey 2010, among others). Aspects such as the extent of contact, the density of speakers of each language, the relative prestige of each language, or the knowledge and relative use of each language by the speakers are usually invoked to explain transfer of features or convergence. However, other factors of a psychosocial nature also play a determining role in the adoption of linguistic features by speakers of languages in contact. Work along these lines includes that of Romera and Elordieta (2013) on Catalan intonational features in Spanish, Kozminska (2019) on the presence of English intonational features on the variety of Polish spoken by Polish immigrants, and Elordieta and Romera (2020a) on falling intonational contours in yes/no questions typical of Basque in the variety of Spanish in the Basque Country.

Elordieta and Romera (2020a) investigated the presence of (rising-)falling intonational configurations at the end of information-seeking absolute interrogatives in Basque Spanish as a feature that is received from Basque, directly or indirectly. Our study focused on the cities of Bilbao and San Sebastian. These two cities have always been in contact with Basque, although Spanish is the dominant language. In San Sebastian, a vernacular variety of Gipuzkoan Basque is still spoken, and in Bilbao, a variety of northern Bizkaian was spoken until the beginning of the last century. Next to the two cities, there are towns where Bizkaian and Gipuzkoan Basque are still spoken, and historically, there has been close contact with inhabitants of those towns in the form of commercial relationships and local immigration to the two capital cities. Bilbao and San Sebastian have populations of 343,430 and 181,652 , respectively $(858,236$ and 327,428 when the urban areas they form together with smaller towns that surround them are considered; cf. (Eustat 2019)). The 1,185,664 inhabitants of the Bilbao and San Sebastian metropolitan areas amount to $54 \%$ of the population of the Autonomous Community of the Basque Country $(2,188,017)$.

Elordieta and Romera (2020a) found that 79\% of all information-seeking yes/no questions had final falling configurations in these two cities. The circumflex nuclear contour of information-seeking yes/no interrogatives in Basque Spanish is found in Castilian Spanish in absolute interrogatives that are not information seeking in nature, but rather have other pragmatic nuances, at least in elicited speech (from read sentences or from Discourse Completion Tasks). Escandell Vidal (1998, 1999, 2017) claims that a circumflex contour can appear in yes/no echo questions, used to express surprise at what the interlocutor has just said or to beg a clarification from the interlocutor of what (s)he has just uttered (cf. also (Estebas-Vilaplana and Prieto 2010; Hualde and Prieto 2015, p. 378)). Torreira and Floyd (2012) find this contour in yes/no questions that serve the discourse function of signaling that the topic of the discourse is being followed up, or that the "course of action" is maintained. In our corpus, the absolute questions were of the genuine information-seeking type, which, in Castilian Spanish, have been reported to have a final rising configuration. In order to be able to establish a more direct comparison with central varieties of Peninsular Spanish, we recorded seven speakers from Madrid in conversations of the same type as those in the Basque Country. The results showed that two-thirds of the information-seeking absolute interrogatives ended in a rising configuration (a percentage that rose to $84 \%$ for five of the seven speakers). Thus, the relative frequency of appearance of rising and falling configurations was roughly the opposite in Basque Spanish and Madrid Spanish.

This influence could be understood in diachronic terms as a historical transfer by native Basque speakers to their Spanish, followed by a consolidation of falling contours as a characteristic of Basque Spanish. Other northern varieties of Spanish, such as those spoken in Galicia, Asturias, and Cantabria, present falling final contours in absolute interrogatives, especially in non-urban areas. However, 
the falling contours are different from those found in Basque Spanish. For a detailed comparison, the reader is referred to Elordieta and Romera (2020a). ${ }^{1}$

In order to explain this variation, we tested several social factors, namely the attitudes towards the Basque language and the Basque ethnolinguistic group and the degree of contact with Basque. Our results showed that the attitudes speakers presented provided a high degree of explanation for the prosodic convergence of Spanish and Basque in two cities that were analyzed (Elordieta and Romera 2020a). Speakers who showed more positive attitudes towards Basque and the Basque-speaking group also produced higher rates of prosodic features present in Basque. The degree of contact was also a determining factor in explaining convergence of prosodic features. Together, the degree of contact with Basque and the attitudes toward this language explained almost $80 \%$ of the variation.

The one question that arises now is whether the situation is different in smaller towns where a vernacular variety of Basque has always been dominant. First, it is worth investigating whether a higher degree of contact with Basque and the Basque ethnolinguistic group in non-urban towns determines an even higher use of final falls in yes/no questions. Second, if the population in non-urban towns has positive attitudes towards Basque and the Basque ethnolinguistic group, it would be interesting to know whether this fact also leads to higher percentages of occurrence of falling nuclear contours in absolute interrogatives. These questions are the goal of our present paper.

\section{Previous Study on the Prosody of Spanish in Contact with Basque and the Influence of Social Factors}

\subsection{Final Falling Contours in Absolute Interrogatives in Bilbao and San Sebastian}

In Elordieta and Romera (2020a), we conducted a study on the intonation of information-seeking absolute interrogatives in Spanish as spoken in Bilbao and San Sebastian. We collected data through sociolinguistic interviews (Silva-Corvalán 2001) from 12 speakers of different linguistic profiles: Spanish monolinguals, L1 Spanish/L2 Basque bilinguals, and L1 Basque/L2 Spanish bilinguals. There were six females and six males, all between 35 and 55 years old and with secondary education at least.

The study revealed that in Bilbao and San Sebastian, 79\% of all information-seeking yes/no questions (136 of a total of 172) had final configurations with a rising-falling circumflex contour. This contour can be transcribed in the autosegmental-metrical annotation system as $\left.\mathrm{L}+\mathrm{i}_{\mathrm{i}}\right) \mathrm{H}^{*}(\mathrm{H}) \mathrm{L} \%$, that is, a rising pitch accent with the peak on the stressed syllable followed by a drop in tone in the final syllable. The pitch reached in the stressed syllable may exceed the level reached in the rest of the sentence, hence the upstep diacritic ' $i$ '. On the other hand, the high tonal level may be maintained in the final syllable of the interrogative sentence and may fall even more abruptly towards the end, hence the possible presence of the high tone $\mathrm{H}$ in the boundary tone (subject to intra- and inter-speaker variation). Figure 1 shows an intonation contour of an absolute interrogative sentence in Basque Spanish, corresponding to a male bilingual speaker from San Sebastian with Spanish as his native language.

1 There is a growing literature on the presence of prosodic features of one language on another it is in contact with. For a comprehensive bibliography, which includes studies on Spanish in contact with other languages in the Iberian Peninsula and in America, the reader can consult Elordieta and Romera (2020a). 


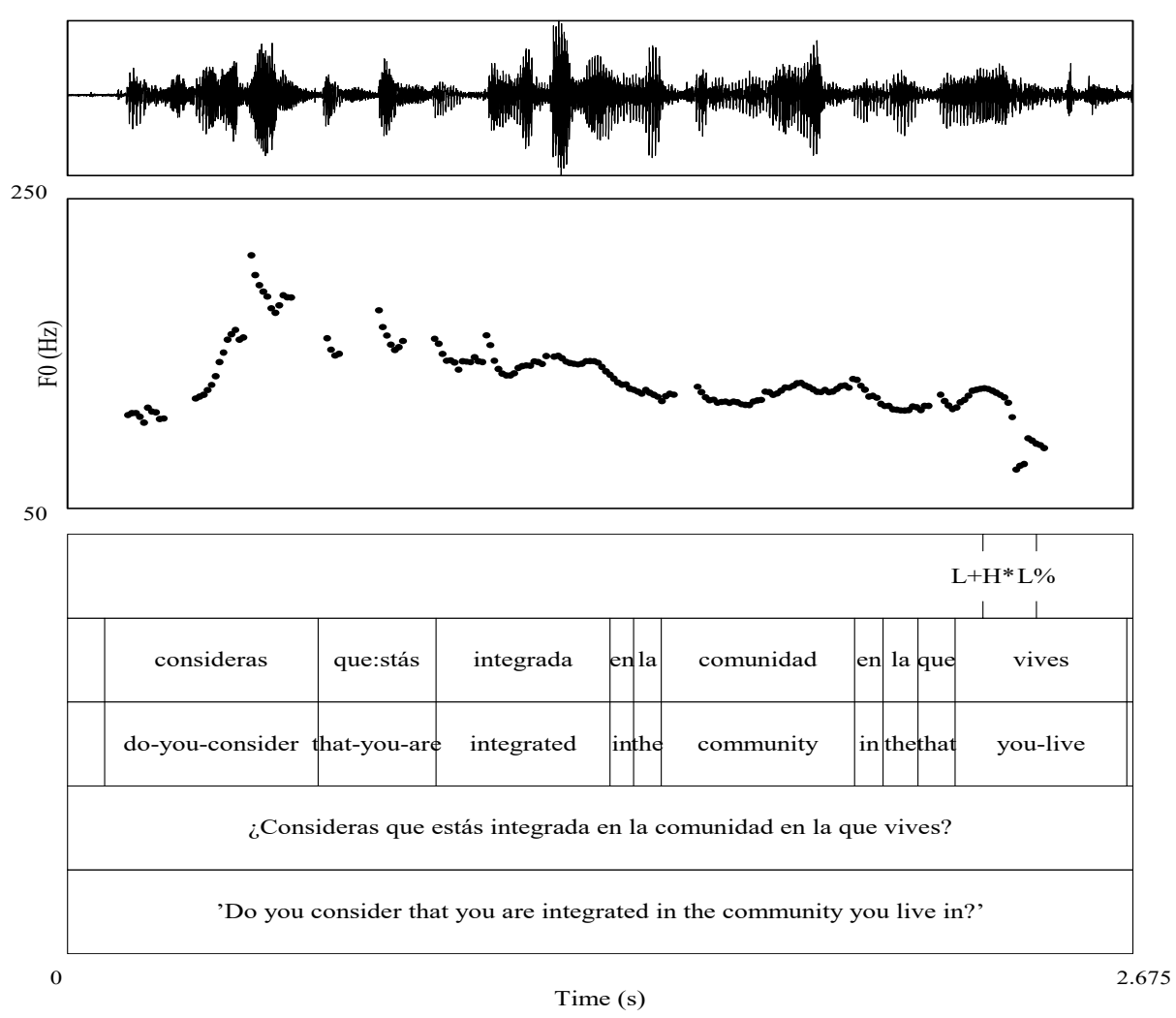

Figure 1. F0 contour of an absolute interrogative statement in Basque Spanish by a male L1 Spanish/L2 Basque speaker from San Sebastian.

Final rising or sustained pitch configurations are found in $21 \%$ of the information-seeking yes/no questions (36 interrogatives). Of these, only 10 interrogatives present the $\mathrm{L}^{*} \mathrm{H} \%$ configuration of Castilian Spanish ( $6 \%$ of the total number of absolute questions), the rest having a rising nuclear accent, $\mathrm{L}+(\mathrm{i}) \mathrm{H}^{*}\left({ }_{\mathrm{i}}\right) \mathrm{H} \%$.

The finding that only $21 \%$ of information-seeking absolute interrogatives end in rising nuclear contours in Basque Spanish contrasts with the traditional description of neutral information-seeking absolute interrogatives in Castilian Spanish (central and southern varieties). They are characterized primarily by rising final contours in which the final stressed syllable of the statement presents a low tonal value followed by a rising intonation in the last syllable (see, among others, Navarro Tomás (1944), Quilis (1993), Face (2008), Hualde (2005), Estebas-Vilaplana and Prieto (2010), Henriksen (2010), Henriksen and García-Amaya (2012), and Hualde and Prieto (2015)). In Sp_ToBI, this tone is transcribed as $\mathrm{L}^{*} \mathrm{H} \%$.

Given that falling circumflex tones in absolute interrogatives are typical of Basque (cf. (Elordieta 2003; Gaminde et al. 2016; Robles-Puente 2012; Elordieta and Hualde 2014)), Elordieta and Romera (2020a) attributed the high frequency of falling circumflex tones in the Spanish spoken in the Basque Country to an influence from Basque (cf. also (Robles-Puente 2012; González and Reglero 2021)). Figure 2 shows an intonation contour of an absolute interrogative statement in Gipuzkoan Basque (example taken from (Elordieta and Hualde 2014, p. 457)). 


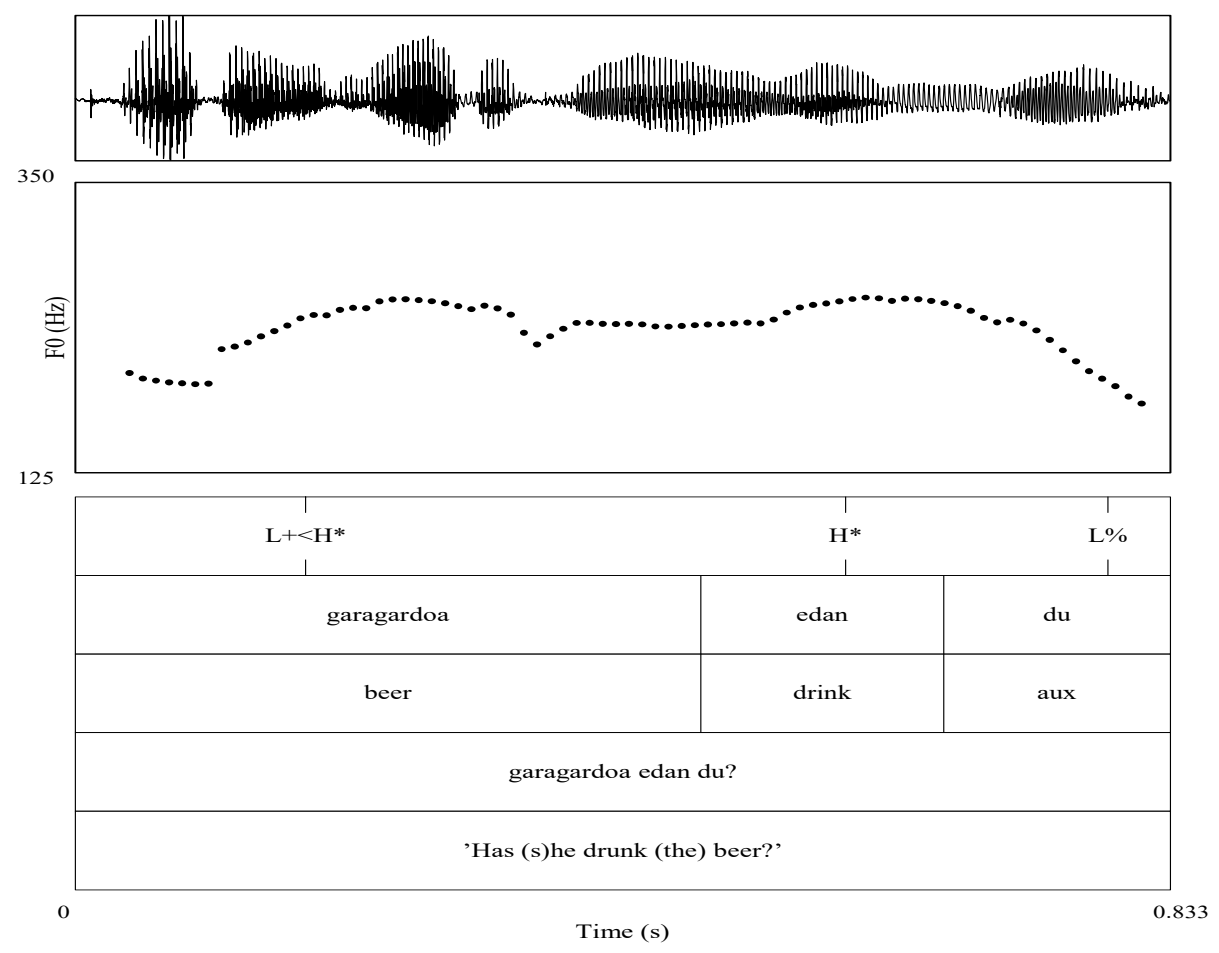

Figure 2. F0 contour of an absolute interrogative statement in Gipuzkoan Basque by a female speaker (example from (Elordieta and Hualde 2014, p. 457)).

Several studies have reported the existence of falling intonation patterns in absolute interrogatives in Central Castilian Spanish. These interrogative sentences are not genuine information-seeking questions, but rather have pragmatic connotations of echo, imperative, or confirmatory questions, in which the speaker is attributing the content of the interrogative to another person (cf. (Escandell Vidal 1998, 1999, 2017; Estebas-Vilaplana and Prieto 2010; Hualde and Prieto 2015; Henriksen et al. 2016), among others). These are annotated by the above-mentioned sources as $\mathrm{L}+\mathrm{H}^{*}$ $\mathrm{L} \%$, with a rise in pitch on the nuclear syllable above the level of other previous high tones (hence also annotated as $\mathrm{L}+\mathrm{iH}^{*} \mathrm{~L} \%$ by (Torreira and Floyd 2012)).

In spontaneous speech in Madrid Spanish, Torreira and Floyd (2012) claim that circumflex tones may be even more common than rising tones, which suggests that the most neutral intonation patterns are not necessarily the most common in conversational speech (cf. (Hualde and Prieto 2015)). Torreira and Floyd (2012) mention several but disperse pragmatic and discourse contexts where the circumflex contour occurs, but they come up with the generalization that this type of contour is mainly used as a "topic follow-up", and secondarily as a signal that the speaker is "maintaining the course of action". These interrogatives appear with the following functions in discourse in the corpus analyzed by these authors: responding to a previous question, providing receipt of news, initiating a repair, checking the listener's attention during a statement, or providing a pre-announcement during a statement.

Henriksen et al. (2016) also observed that rising tones are rare in spontaneous speech among speakers of Manchego Spanish, a variety of Castilian Spanish spoken to the south of Madrid. Inspired by Escandell Vidal (1998), the authors associated the rising contours with statements in which the content of the question is attributable to the speaker (in other words, a genuine information-seeking question). Falling contours are more common in interrogative sentences in which the content of the question can be attributed to another person, be it the speaker's conversation partner or another, external party.

The absolute interrogatives analyzed by Elordieta and Romera (2020a) in Basque Spanish, however, corresponded to a genuine search for information. The absolute interrogative statements 
occurred in the context of a semi-directed interview or conversation in which the interviewer asked questions that sought information about the interviewee that was unknown to the interviewer. Thus, the comparison remains legitimate: The unmarked pattern in Castilian Spanish for neutral, information-seeking absolute interrogatives is a final rise, but in Basque Spanish, it is a final fall. In any case, with the aim of settling the issue, Elordieta and Romera (2020b) carried out an analysis of the nuclear configurations of absolute interrogatives in Madrid Spanish by applying the same methodology followed in Elordieta and Romera (2020a) to seven speakers of Madrid Spanish so that the data could be directly comparable. The main result in Elordieta and Romera (2020b) was that in Madrid Spanish, $66.3 \%$ of information-seeking questions ended in rising contours, two-thirds of the total. In Basque Spanish, Elordieta and Romera (2020a) had found only 21\% of information-seeking absolute interrogatives ending in a rising contour. That is, whereas final falls are the norm in Basque Spanish (79\%), final rises are the norm in Madrid Spanish (only 33.7\% of final falls). The pervasive presence of final falling configurations in Basque Spanish is such that there are no subjects with fewer than $64 \%$ of rising-falling nuclear contours, and two of the twelve subjects analyzed had all interrogatives ending in this type of contour, i.e., $100 \%$ of final falls, with no final rises at all.

\subsection{The Role of Degree of Contact with Basque and Linguistic Attitudes towards Basque on the Prosody of Spanish in Contact with Basque in Urban Areas}

In principle, one could consider the hypothesis that there could exist a correlation between the frequency of occurrence of final falling contours and the degree of knowledge of Basque. However, as shown in Table 1 below, Elordieta and Romera (2020a) found no significant differences in the frequency of occurrence of falling or rising contours in absolute interrogatives depending on the linguistic profile of the subjects (i.e., whether they were monolingual speakers of Spanish, L1 Spanish/L2 Basque speakers, or L1 Basque/L2 Spanish speakers). There were no differences depending on the city of origin (Bilbao or San Sebastian) or on the gender of the speakers, either.

Table 1. Numbers and percentages of information-seeking yes/no interrogatives with rising-falling and rising final contours (Falls and Rises, respectively) for each linguistic profile in San Sebastian and Bilbao.

\begin{tabular}{ccccccc}
\hline & \multicolumn{2}{c}{ Monolingual Spanish } & \multicolumn{2}{c}{ L1 Spanish/L2 Basque } & \multicolumn{2}{c}{ L1 Basque/L2 Spanish } \\
\hline & SSeb & Bilbao & SSeb & Bilbao & SSeb & Bilbao \\
\hline Falls & $19(70 \%)$ & $22(73 \%)$ & $22(76 \%)$ & $25(89 \%)$ & $28(85 \%)$ & $18(78 \%)$ \\
\hline Rises & $8(30 \%)$ & $8(27 \%)$ & $7(24 \%)$ & $3(11 \%)$ & $5(15 \%)$ & $5(22 \%)$ \\
\hline
\end{tabular}

These data indicate that at least $70 \%$ of interrogatives of all speakers ended in a fall in all groups. Although the monolingual group had a lower production of falling contours as compared to the other groups, no statistical correlation was found with the linguistic profiles (chi-square $=12.000 ; p=0.285$ for Bilbao; and chi square $=6.000 ; p=0.306$ for San Sebastian).

Rather, Elordieta and Romera (2020a) found a stronger relationship between the frequency of occurrence of final falling configurations with individual social factors, such as (a) the attitudes that each individual has towards Basque and the Basque ethnolinguistic group, and (b) the degree of contact of each individual with Basque and the Basque ethnolinguistic group. With respect to attitudes, all speakers expressed positive attitudes towards the Basque language and the Basque group in both cities. A total of $75.1 \%$ of the speakers showed very positive attitudes and only $24.9 \%$ showed not-so-positive attitudes. However, it was precisely the speakers who showed not-so-positive attitudes who also showed less production of downfalls (between $64 \%$ and $75 \%$ of falling interrogatives), as opposed to speakers more inclined towards Basque, whose production of falls was higher $(77 \%$ to $100 \%$ ). Despite this, the attitudinal factor could only account for roughly $50 \%$ of the variation $\left(R^{2}=0.466, F(1,10)=8.721, p=0.01\right)$. In contrast, the degree of contact accounted for $70 \%$ of the 
variation. Speakers with lower contact levels produced lower percentages of final falling contours (between $64 \%$ and $80 \%$ ), while speakers with a higher contact value produced between $83 \%$ and $100 \%$ of final falls.

The degree of contact, however, seems to be a relevant factor in explaining the linguistic behavior of certain L1 Basque speakers, whose attitudinal value is positive but who had a percentage of interrogative falling circumflex contours relatively lower than expected for this attitudinal value. The substantial exposure not only to Basque Spanish, but also to other Peninsular Spanish varieties, as business trips to other parts of Spain might lead to producing more interrogative utterances with this type of final contour.

Finally, when both social factors were combined, $80 \%$ of the differences in the percentages of circumflex contours could be accounted for. That is, those speakers who had a closer contact with Basque or with speakers of Basque and who had favorable attitudes towards Basque and speakers of Basque presented higher percentages of final falling intonational contours $\left(R^{2}=0.807, \mathrm{~F}(2,9)=18.844\right.$; $p=0.001)$. Therefore, although the degree of contact may account for a higher percentage of the production of falling contours, the combination of both factors provided a better explanation of the results.

\section{Spanish Prosody and Social Factors in Non-Urban Basque-Speaking Areas}

\subsection{Methodology}

For the present study, we recorded speakers from two rural or non-urban small towns: Lekeitio, in the same province as Bilbao, and Ibarra, in the same province as San Sebastian. Their populations as of 2020 were 7227 and 4306, respectively. The criteria for speaker selection were the same as those followed for Bilbao and San Sebastian. There were six speakers in each town (i.e., 12 in total), and they belonged to the same three linguistic profiles as in Bilbao and San Sebastian: Spanish monolinguals, L1 Spanish/L2 Basque bilinguals, and L1 Basque/L2 Spanish bilinguals. Gender, age, and level of education were also taken into account. Therefore, six women and six men between the ages of 35 and 55 years old and with a medium-high education level were recorded. (All subjects gave their informed consent for inclusion before they participated in the study. The ethic code for the research: CEISH/115/2012/ELORDIETA ALCIBAR)

The speakers were recorded using the same sociolinguistic interviews as for Bilbao and San Sebastian (Silva-Corvalán 2001). Two interviews were conducted with each experimental subject. The first interview was one in which the subjects were asked questions by the interviewers. With such an interview, declarative utterances were obtained from the subjects. The questions were divided into three modules. The first module contained questions on the subjects' degree of knowledge of the two languages in contact, Basque and Spanish. The second module had questions related to the degree of use of each of these languages. In the third module, the subjects were questioned on their attitudes towards Basque and the Basque ethnolinguistic group: for instance, whether they thought that speaking Basque improved the social image of a person, whether, in their opinion, knowing and speaking Basque was useful in their personal and professional lives, or whether they thought that Basque should be taught obligatorily. The questions were written on sheets of paper in the form of bulleted topics rather than in the form of full questions, the idea being that the interviewer posed the questions in as natural a style as possible, not as read speech.

The second interview was one in which the subjects took the role of interviewers and asked their interlocutors (i.e., the interviewers of the first part) the same questions that they had been asked. This way, a number of absolute and partial interrogative utterances (i.e., yes/no and wh-questions, respectively) were recorded from the subjects. The interviewers were speakers of Basque Spanish and members of the community, and had been trained to conduct the interviews. That way, we fostered a situation in which our experimental subjects could feel more at ease with the activity, talking to a person that speaks the same variety of Spanish as theirs. This could favor a more natural production 
from the subjects. The interviewers also served the role of selecting speakers who fulfilled the social and linguistic profiles described above.

The recordings took place in quiet rooms at the speakers' homes or workplaces in order to facilitate an optimal level of confidence and comfort for the speaker. The interviews were recorded with a Tascam DR-100 digital recorder through a built-in omni-directional microphone pointing towards the subjects but able to capture the speech of the two participants. The audio was recorded with a sampling rate of $44,000 \mathrm{~Hz}$ in wav format. The conversations were also recorded on video with a Sony video camera held on a tripod, with the objective of analyzing the speakers' level of (dis)comfort, relaxation, or nervousness while answering the questions about their attitudes towards Basque and the Basque ethnolinguistic group. In all, $9 \mathrm{~h}$ and $25 \mathrm{~min}$ of conversations were recorded for the 12 subjects, with an average of $47 \mathrm{~min}$ per subject. This is a remarkable similarity with our recordings in Bilbao and San Sebastian, where we collected $9 \mathrm{~h}$ and $20 \mathrm{~min}$ of conversations for 12 speakers, with an average of 46 min per speaker. A total of 360 declarative utterances, 155 absolute interrogatives, and 201 partial interrogatives were segmented-a similar amount in comparison with the one for Bilbao and San Sebastian (albeit with fewer absolute interrogative utterances). As for Bilbao and San Sebastian, we collected more declarative utterances than interrogatives because speakers produce more utterances when they respond than when they ask. We collected an average of 30 declarative utterances as well as almost 13 absolute interrogatives and 17 partial interrogatives.

Like for Bilbao and San Sebastian, in this article, only neutral or information-seeking absolute interrogatives were considered, without any pragmatic bias on the part of the speaker uttering the question. That is, the interrogative sentences corresponded to a genuine search for information. This choice was motivated by the fact that these are the sentence types that have the most significantly different intonational contours in Castilian Spanish and Basque. Hence, any intonational features in yes/no interrogatives in the Spanish variety of the Basque Country that differ from the typical Castilian Spanish features and which resemble those of Basque are more easily discernible. They commonly end in rising contours in the former (cf. (Face 2008; Estebas-Vilaplana and Prieto 2010; Hualde and Prieto 2015; Henriksen et al. 2016; Elordieta and Romera 2020b)) and in falling contours in the latter (cf. (Elordieta 2003; Gaminde et al. 2016; Robles-Puente 2012; Elordieta and Hualde 2014; Eguskiza et al. 2017)). A higher frequency of final falling intonational configurations would suggest an influence from Basque. In this regard, Elordieta and Romera's (2020b) study on information-seeking absolute interrogatives in Madrid Spanish is eloquent, as it uses the same methodology as the one in Elordieta and Romera (2020a), and the results are thus directly comparable. In this variety of Castilian Spanish, two-thirds of the information-seeking yes/no questions end in a rising contour, and thus only one-third of these types of questions end in a falling contour.

With respect to the social factors analyzed, the degree of contact, and the attitudinal component, all answers were coded both qualitative and quantitatively. From a quantitative point of view, each speaker was given two values, one regarding the degree of contact they maintained with the Basque language, and other regarding the attitude they showed towards the Basque language and the Basque ethnolinguistic group. Following studies in the field, each response was given a value on a scale of 1 to 3,1 being the lowest value and 3 the highest. Then, the mean value of these ratings was calculated for each speaker, and the resulting number was assigned to each of them and taken as an index. We called these the contact value and attitudinal value, respectively (Elordieta and Romera 2020a, p. 25).

Finally, although the number of tokens analyzed may be judged to be low, it must be taken into account that conversational speech is not so straightforward to analyze. Overlaps, distortions, and interruptions in natural speech hinder the task of segmentation. The annotation of prosodic features is complicated as well due to uncontrolled phonological processes of resyllabification and phonetic lenition of consonants and vowels frequently observed in informal and fast speech. Moreover, the phonetic analysis was combined with a sociolinguistic analysis of the 12 speakers. In the end, 
the size of the data was roughly similar to the one for San Sebastian and Bilbao, and it will hence allow for a direct comparison as well.

\subsection{Final Intonational Configurations in Absolute Interrogatives in Lekeitio and Ibarra}

Of the 155 absolute questions in Lekeitio and Ibarra, we finally analyzed 137 utterances. We had to discard 18 interrogatives because they did not represent genuine information-seeking absolute interrogatives. Some of them were disjunctive (i.e., 'do you like $X$ or do you prefer $Y^{\prime}$ '?), and others were uttered without a verb, as not-full-fledged questions (e.g., 'place of origin?'). In the two towns, $93.4 \%$ of all information-seeking yes/no questions ended in final falling contours (128 out of 137). There was a slightly bigger percentage of falls in Lekeitio than in Ibarra, but the difference was small and, hence, not significant: $95.5 \%$ in Lekeitio (64 final falls out of 67 interrogatives) and $91.4 \%$ in Ibarra (64 final falls out of 70 interrogatives). Only $6.6 \%$ of all information-seeking yes/no questions ended in rising contours (9 out of 137), the most frequent contour being $\mathrm{L}+\left({ }_{i}\right) \mathrm{H}^{*}\left({ }_{\mathrm{i}}\right) \mathrm{H} \%$, that is, a rising nuclear accent with a peak on the nuclear syllable followed by a further rise on the final syllable, sometimes reaching a very high level, hence the upstepped diacritic. We only found one case of the contour reported traditionally as the most frequent one for Castilian Spanish, $\mathrm{L}^{*} \mathrm{H} \%$, that is, a low tone on the nuclear syllable followed by a high boundary tone.

Of all the information-seeking interrogatives, $53.3 \%$ were of the rising-falling circumflex type found in San Sebastian and Bilbao, that is, a rising nuclear tone with a peak on the tonic syllable $\left(\mathrm{L}+\mathrm{H}^{*}\right)$ followed by an L\% or HL\% boundary tone. The latter is distinguished from plain L\% because the high tone level of the nuclear accent is maintained up to the middle of the final syllable of the word (also final in the utterance) before it falls to a low pitch level. In many of the instances, an upstepped pitch level was observed on the accentual $\mathrm{H}^{*}$ tone, which can be transcribed in a Tones and Break Indices (ToBI) model as $\mathrm{L}+(\mathrm{i}) \mathrm{H}^{*}$. Thus, the general shape for the most common nuclear contour in information-seeking interrogatives in Lekeitio and Ibarra is $\mathrm{L}+\left({ }_{i}\right) \mathrm{H}^{*}(\mathrm{H}) \mathrm{L} \%$. As we said, this is also the most common type of contour in San Sebastian and Bilbao (69.5\%, cf. Elordieta and Romera 2020a). Figure 3 shows a pitch track of an information-seeking yes/no question with an $\mathrm{L}+\mathrm{H}^{*} \mathrm{~L} \%$ contour uttered by a male Spanish monolingual speaker from Lekeitio.

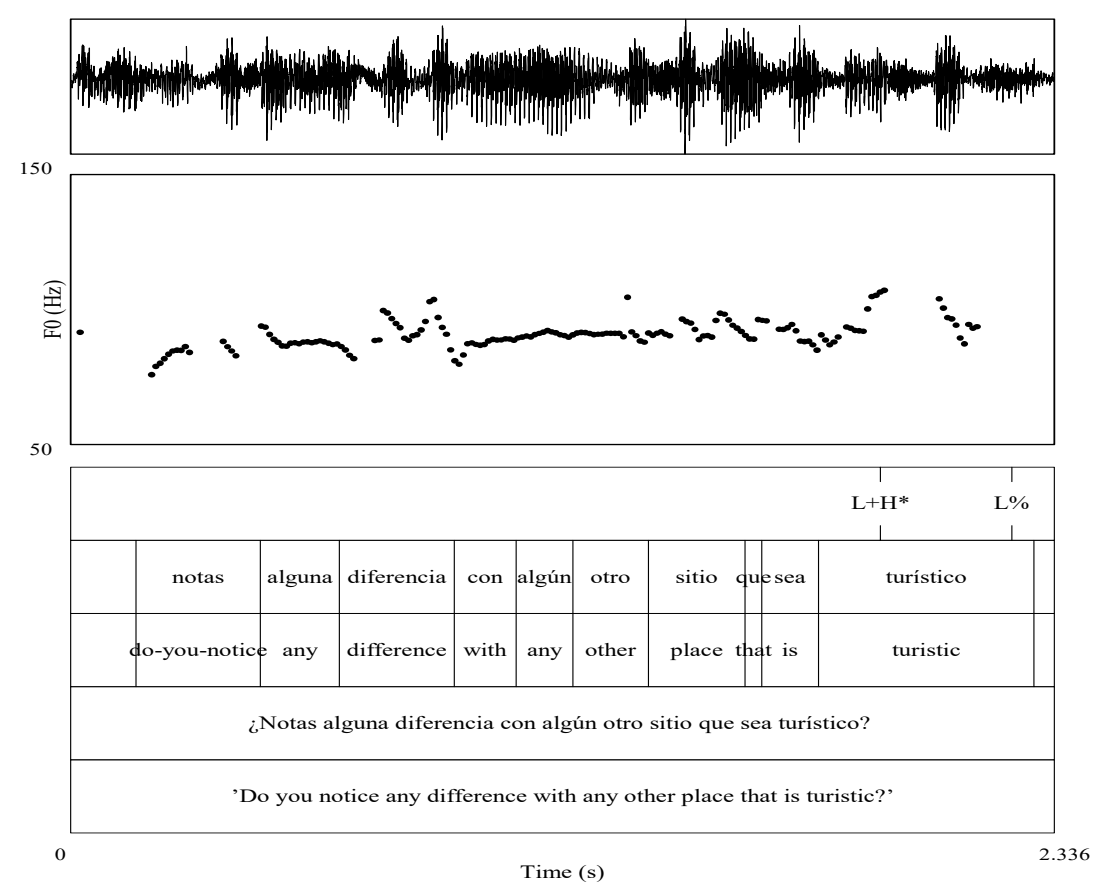

Figure 3. F0 contour of an absolute interrogative statement in Basque Spanish, by a male monolingual Spanish speaker from Lekeitio. 
In several instances of final falling contours, the nuclear accent was not a rising one, or at least not clearly, and an $\mathrm{L} \%$ boundary tone followed. We chose the label $\mathrm{H}^{*} \mathrm{~L} \%$ for this type of contour, shown by $38.7 \%$ of all the information-seeking absolute interrogatives. Figure 4 illustrates an example, uttered by a female L1 Basque speaker from Ibarra. The high F0 level at the beginning of the syllable with the nuclear accent (i.e., the syllable ke, in the word euskera 'Basque') is a microprosodic effect of the voiceless plosive $[\mathrm{k}] .^{2}$

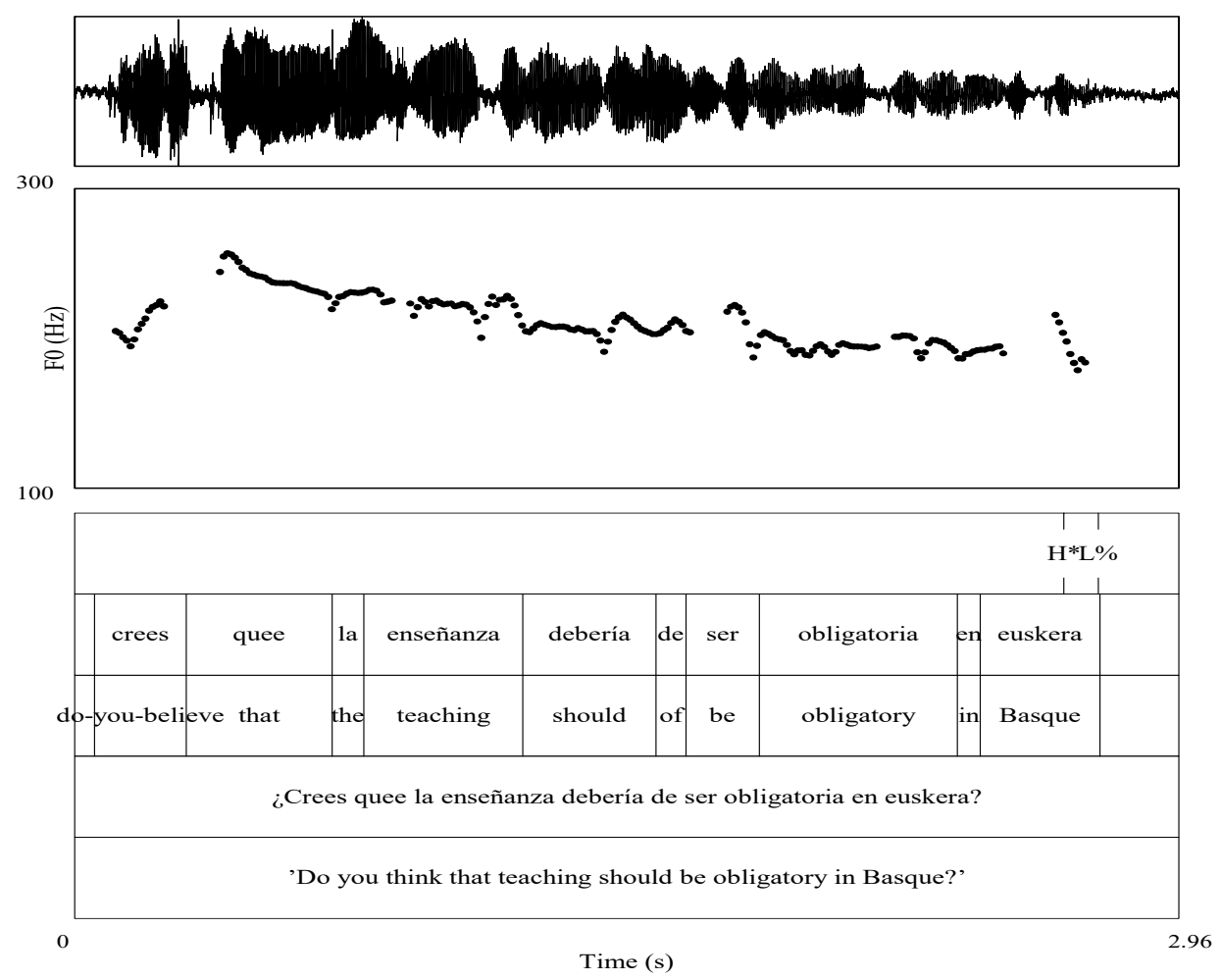

Figure 4. F0 contour of an absolute interrogative statement in Basque Spanish by a female L1 Basque/L2 Spanish speaker from Ibarra.

Finally, Figure 5 illustrates an F0 contour of an utterance with a final rising contour by a female L1 Spanish speaker from Lekeitio. ${ }^{3}$

2 The lengthening of word-final vowels is very common in spontaneous speech. In Figure 4, the final vowel of the complementizer que 'that' is written with two vowels to indicate that it is lengthened.

3 An anonymous reviewer asks whether the complexity of the syntactic structure of the interrogative utterances may influence the intonational contour. Since the utterance in Figure 5 (with a final rising configuration) is shorter and with simpler syntactic constituency than the ones in Figures 1,3 and 4 (with a final falling configuration), the reviewer asks whether a correlation was found between the length and syntactic complexity of the utterances and the falling or rising final contours. However, there is no correlation. On the one hand, in our data there are many short utterances with final falls, such as ¿Estás casado? 'Are you married?', ¿Tienes hijos? 'Do you have children?', ¿Te gusta Lekeitio? 'Do you like Lekeitio?', or ¿Te has fijado? 'Have you noticed?'. On the other hand, among the very few utterances with final rises, there are long utterances such as $i Y$ la persona que viva aquí, debería o tendría que hablar en euskera? 'And the person that lives here, should (s)he or would (s)he have to speak in Basque?'. 


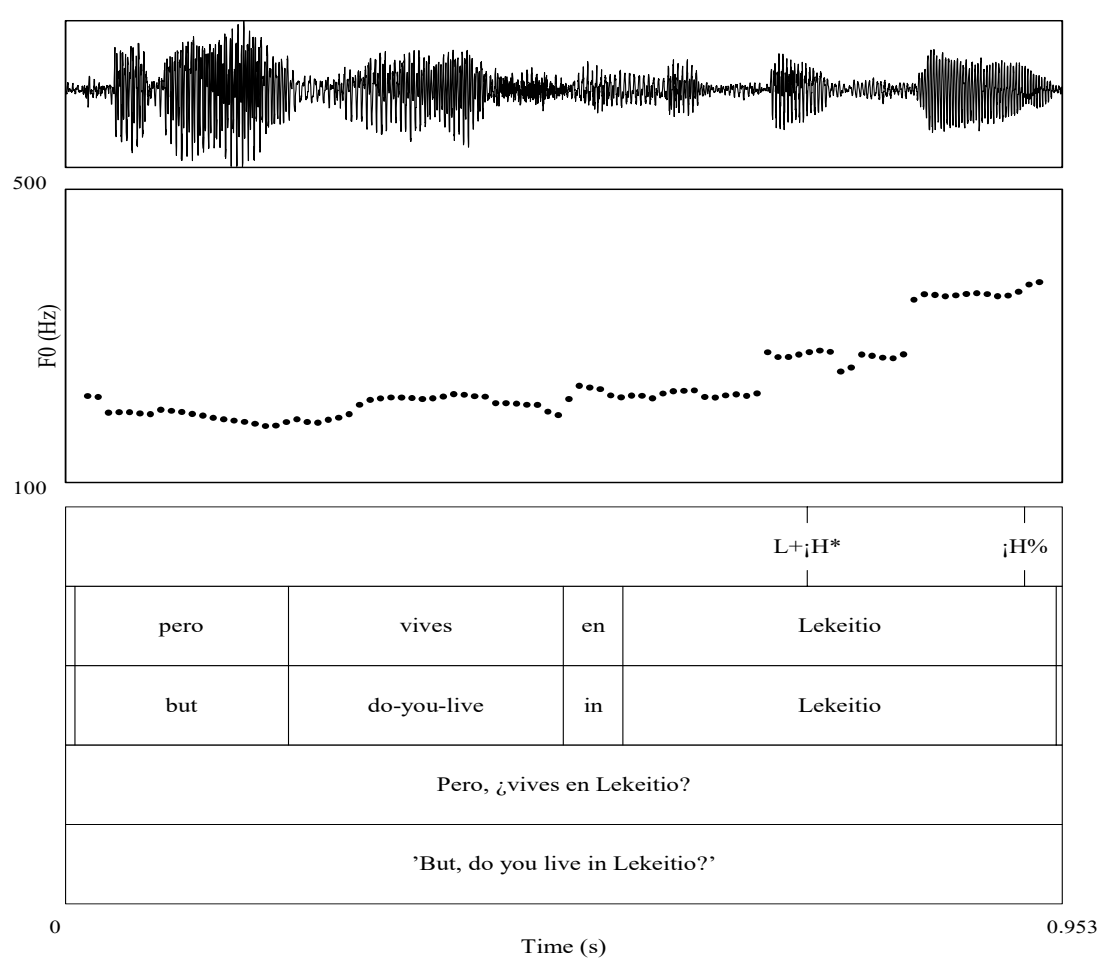

Figure 5. F0 contour of an absolute interrogative statement in Basque Spanish by a female L1 Spanish/L2 Basque speaker from Lekeitio.

\subsection{Social Factors in Ibarra and Lekeitio}

The fact that $93.4 \%$ of information-seeking absolute interrogatives in Ibarra and Lekeitio end in falling contours can be compared to the fact that $79 \%$ of yes/no questions of the same type end in falling contours in Bilbao and San Sebastian, as found by Elordieta and Romera (2020a). Within the Basque Country, then, it seems that falling configurations in information-seeking yes/no questions are more common in non-urban small towns than in cities. The difference is even bigger, of course, when compared to Madrid Spanish, where only 33.7\% of information-seeking yes/no questions end in falls, as recently found by Elordieta and Romera (2020b). These results would suggest that the influence of Basque prosody is stronger in small towns than in cities.

Language dominance does not seem to have an effect on the occurrence of final falls or rises, like in Bilbao and San Sebastian (cf. Elordieta and Romera 2020a). Table 2 shows the percentages of final falling configurations depending on the speakers' linguistic profiles: monolingual Spanish, L1 Spanish, and L1 Basque. Although L1 Spanish speakers appear to have a smaller frequency of use of final falling configurations compared to the other two groups, the cross-tabulation test did not return a significant difference $\left(\chi^{2}=1.262 ; p=0.532\right)$. It is noteworthy that monolingual speakers produced more falling configurations than bilingual speakers.

Table 2. Numbers and percentages of information-seeking yes/no interrogatives with rising-falling and rising final contours (Falls and Rises, respectively) for each linguistic profile in the two towns combined: Lekeitio and Ibarra.

\begin{tabular}{lccc}
\hline & Monolingual Spanish & L1 Spanish/L2 Basque & L1 Basque/L2 Spanish \\
\hline Falls & $49(96 \%)$ & $37(90.2 \%)$ & $42(93.3 \%)$ \\
Rises & $2(4 \%)$ & $4(11.8 \%)$ & $3(6.7 \%)$ \\
\hline
\end{tabular}

Tables 3 and 4 show the frequencies of occurrence of final falls and rises in absolute interrogatives in Lekeitio and Ibarra, respectively. It is in Lekeitio where L1 Spanish bilinguals have fewer falls, 
but the differences with the other groups are not statistically significant $\left(\chi^{2}=2.844 ; p=0.241\right)$. In Ibarra, there is no difference between groups. It is rather telling that monolingual Spanish speakers in Lekeitio have $100 \%$ of final falling configurations, even more than L1 Basque speakers.

Like in Bilbao and San Sebastian, gender is not a significant factor. Males produced 71 informationseeking absolute interrogatives, of which 67 ended in a falling configuration and four ended in a rising contour $(94.3 \%$ and $5.7 \%$, respectively). Females produced 61 final falls and five final rises (92.4\% and $7.6 \%$, respectively). This similarity across genders holds in each town. Table 5 below shows the percentages of falling and rising contours according to the speakers' gender.

Table 3. Numbers and percentages of information-seeking yes/no interrogatives with rising-falling and rising final contours (Falls and Rises, respectively) for each linguistic profile in the town of Lekeitio.

\begin{tabular}{lccc}
\hline & Monolingual Spanish & L1 Spanish/L2 Basque & L1 Basque/L2 Spanish \\
\hline Falls & $26(100 \%)$ & $17(89.5 \%)$ & $21(95.4 \%)$ \\
Rises & $0(0 \%)$ & $2(10.5 \%)$ & $1(4.6 \%)$ \\
\hline
\end{tabular}

Table 4. Numbers and percentages of information-seeking yes/no interrogatives with rising-falling and rising final contours (Falls and Rises, respectively) for each linguistic profile in the town of Ibarra.

\begin{tabular}{lccc}
\hline & Monolingual Spanish & L1 Spanish/L2 Basque & L1 Basque/L2 Spanish \\
\hline Falls & $23(92 \%)$ & $20(91 \%)$ & $21(91.3 \%)$ \\
Rises & $2(8 \%)$ & $2(9 \%)$ & $2(8.7 \%)$ \\
\hline
\end{tabular}

Table 5. Percentage of information-seeking yes/no interrogatives with falling and rising final contours according to speakers' gender.

\begin{tabular}{ccc}
\hline & Female & Male \\
\hline Falls & $61(94.3 \%)$ & $67(92.4 \%)$ \\
Rises & $5(5.7 \%)$ & $4(7.6 \%)$ \\
Total & $66(100 \%)$ & $71(100 \%)$ \\
\hline
\end{tabular}

Consequently, our data indicate that in Lekeitio and in Ibarra, the production of falling interrogatives is the norm among the speakers interviewed. Table 6 below illustrates that for $75 \%$ of the speakers (9 out of 12), 90-100\% of their information-seeking absolute interrogatives had final falling contours (these speakers are highlighted in gray). For $16 \%$ of the speakers ( 2 out of 12 ), $86-87.5 \%$ of this type of interrogative showed falling contours, and only one person had $78 \%$ of final falling configurations. That is, the frequency of occurrence of final falling intonational contours is $78-100 \%$, with three-fourths of the speakers having frequencies of $90-100 \%$. In fact, half the speakers in Ibarra and Lekeitio (6 out of 12, cf. Table 6) had all their information-seeking absolute interrogatives displaying final falling tonal configurations. These data indicate that the falling pattern is widespread in the area and that differences in the production of interrogatives are minimal.

In spite of this, we were interested in contrasting these results with those in the cities and seeing to what extent social factors were playing similar roles, i.e., whether the degree of contact and attitude towards the Basque language and the Basque ethnolinguistic group could still be playing a role in this minimal variation. The presence of Spanish in the cities of Bilbao and San Sebastian is stronger than in smaller, non-urban towns, where a vernacular variety of Basque has always been dominant. Hence, we would like to know whether a higher degree of contact with Basque and the Basque ethnolinguistic group in non-urban towns leads to a higher use of final falls in yes/no questions. In the same line, regarding the attitudinal factor, which proved relevant in explaining the variation in Bilbao and San Sebastian, we would like to know whether a positive attitude also led to higher percentages of occurrence of falling nuclear contours in absolute interrogatives in Lekeitio and Ibarra. 
Table 6. Percentage of interrogative sentences ending in falling contours according to the speakers' language profile ${ }^{4}$.

\begin{tabular}{ccccc}
\hline & & Language Profile & $\mathbf{n}$ & $\%$ \\
\hline \% Falls & 78.0 & L1Sp & 1 & $8.3 \%$ \\
\hline & 86.0 & L1Bas & 1 & $8.3 \%$ \\
\hline & 87.5 & Mon & 1 & $8.3 \%$ \\
\hline & 90.0 & L1BasL1Sp & 2 & $16.7 \%$ \\
\hline & 91.0 & L1Sp & 1 & $8.3 \%$ \\
\hline Total & 100.0 & 2Mon 2L1BasL1Sp & 6 & $50 \%$ \\
\hline
\end{tabular}

With regard to the degree of contact with Basque, it showed correlation with the linguistic profile of the speakers $(p=0.008)$ (cf. Table 7 , where the degree of contact is named "contact value"). On a scale from 1 to 3 ( 1 being the lowest degree of contact, and 3 the highest), monolingual speakers ranged between 1.22 and 1.44, while bilingual speakers (L1Sp-L2Bas; L1Bas-L2Sp) scored between 1.67 and 2.33. Monolingual speakers acknowledged having more limited contact with Basque, since although they partially understood the language, and their in-laws, some friends, and people at work could occasionally address them in Basque, their interactions took place only in Spanish. All of them had tried to study Basque at some point in their adult lives. Official schooling in Basque started in the 1990s, so given that the average age of these speakers was 45-55, they only received formal education in Spanish. All of them emphasized the effort and difficulty that studying Basque as an adult meant for them.

Table 7. Degree of contact according to the speakers' language profile and gender.

\begin{tabular}{|c|c|c|c|c|c|}
\hline & & \multicolumn{3}{|c|}{ Language Profile } & \multirow{2}{*}{ Total } \\
\hline & & Monolingual & $\mathrm{L}_{1} \mathrm{Sp} / \mathrm{L}_{2} \mathrm{Bas}$ & $\mathrm{L}_{1}$ Bas/ $\mathrm{L}_{2} \mathrm{Sp}$ & \\
\hline \multirow{7}{*}{ Contact Value } & 1.22 & 2 & 1 & & $3(24.9 \%)$ \\
\hline & 1.33 & 1 & & & $1(8.3 \%)$ \\
\hline & 1.44 & 1 & & & $1(8.3 \%)$ \\
\hline & 1.67 & & 1 & & $1(8.3 \%)$ \\
\hline & 1.89 & & 1 & 1 & $2(16.7 \%)$ \\
\hline & 2.22 & & & 3 & $3(24.9 \%)$ \\
\hline & 2.33 & & 1 & & $1(8.3 \%)$ \\
\hline Total & & 4 & 4 & 4 & 12 \\
\hline
\end{tabular}

However, as shown in Table 8 below, unlike in the urban areas, the degree of contact was not a relevant factor in explaining the differences in the production of falling interrogatives $(p=0.1)$. Three monolingual speakers and one L1Sp speaker whose degree of contact ranged between 1.22 and 1.44 produced all interrogatives $(100 \%)$ in a falling contour. In contrast, the one L1Sp speaker with the highest degree of contact with Basque (2.33) performed only $78 \%$ of her interrogatives as falling.

4 In Tables 6-10, language profiles are abbreviated as follows: Mon for Monolingual, L1Sp for L1 Spanish, and L1Bas for L1 Basque. 
Table 8. Percentage of interrogative sentences ending in falling contours according to degree of contact and speakers' language profile.

\begin{tabular}{|c|c|c|c|c|c|c|c|c|c|}
\hline & & \multicolumn{7}{|c|}{ Contact Value } & \multirow{2}{*}{ Total } \\
\hline & & 1.22 & 1.33 & 1.44 & 1.67 & 1.89 & 2.22 & 2.33 & \\
\hline \multirow{6}{*}{$\%$ Falls } & 78.0 & & \multirow{5}{*}{ Mon } & & & & & \multirow[t]{6}{*}{ L1Sp } & 1 \\
\hline & 86.0 & & & & L1Bas & & & & 1 \\
\hline & 87.5 & & & & & & & & 1 \\
\hline & 90.0 & & & & L1Sp & & L1Bas & & 2 \\
\hline & 91.0 & & & & & L1Sp & & & 1 \\
\hline & 100.0 & $\begin{array}{l}2 \text { Mon } \\
\text { L1Sp }\end{array}$ & & Mon & & & 2 L1Bas & & 6 \\
\hline \multicolumn{2}{|c|}{ Total } & $3^{1}$ & 1 & 1 & 1 & 2 & 3 & 1 & 12 \\
\hline
\end{tabular}

With respect to the other relevant social factor in urban areas, the attitudinal component, certain differences were found between monolingual and bilingual speakers (L1Sp and L1Bas). As shown in Table 9, the former presented slightly less favorable attitudes towards Basque and the Basque ethnolinguistic group (1.67-2.00), while the latter showed very favorable attitudes (2.33-2.56). Monolingual speakers considered that Basque was not very useful for them professionally or in their daily life, and that languages such as English should be promoted as much as Basque. The bilingual groups, on the other hand, considered Basque useful professionally and personally, and supported it being a language spoken by all inhabitants in the Basque Country. These differences, nonetheless, were not statistically significant $(p=0.200)$.

Table 9. Attitudinal values according to the speakers' language profile.

\begin{tabular}{|c|c|c|c|c|c|}
\hline & & \multicolumn{3}{|c|}{ Language Profile } & \multirow{2}{*}{ Total } \\
\hline & & Monolingual & $\mathrm{L}_{1} \mathrm{Sp} / \mathrm{L}_{2}$ Bas & $\mathrm{L}_{1}$ Bas $/ \mathrm{L}_{2} \mathrm{Sp}$ & \\
\hline \multirow{6}{*}{ Attitude Value } & 1.67 & 1 & & & 1 \\
\hline & 1.78 & 2 & 1 & & 3 \\
\hline & 2.00 & 1 & & & 1 \\
\hline & 2.33 & & 1 & 2 & 3 \\
\hline & 2.44 & & 1 & 2 & 3 \\
\hline & 2.56 & & 1 & & 1 \\
\hline Total & & 4 & 4 & 4 & 12 \\
\hline
\end{tabular}

However, no relation was found between the attitudes shown by the speakers and their production of falling contours in information-seeking absolute interrogatives $(p=0.300)$. Unlike in urban areas, where attitudes were clearly influential in the production of falling patterns (cf. Elordieta and Romera 2020a), this factor does not provide an explanation for the small differences in non-urban areas. That is, higher attitudinal values did not lead to higher occurrences of final falling contours. Three monolingual speakers with attitudinal values below 2.00 had $100 \%$ of information-seeking yes/no questions with a final descending contour, while bilingual speakers with attitudes above 2.00 showed lower percentages (cf. Table 10 below). It seems, therefore, that the production of falling intonational patterns in non-urban areas is conditioned by factors other than those governing urban areas. 
Table 10. Percentage of interrogative sentences ending in falling contours according to attitudinal value and speakers' language profile.

\begin{tabular}{|c|c|c|c|c|c|c|c|c|}
\hline & & \multicolumn{6}{|c|}{ Attitudinal Value } & \multirow{2}{*}{ Tota } \\
\hline & & 1.67 & 1.78 & 2.00 & 2.33 & 2.44 & 2.56 & \\
\hline \multirow{6}{*}{$\%$ Falls } & 78.0 & & & & L1Sp & & & 1 \\
\hline & 86.0 & & & & L1Bas & & & 1 \\
\hline & 87.5 & & & Mon & & & & 1 \\
\hline & 90.0 & & & & L1Bas & L1Sp & & 2 \\
\hline & 91.0 & & & & & & L1Sp & 1 \\
\hline & 100.0 & Mon & $\begin{array}{c}2 \text { Mon } \\
\text { L1Sp }\end{array}$ & & & 2 L1Bas & & 6 \\
\hline \multicolumn{2}{|c|}{ Total } & 1 & 3 & 1 & 3 & 3 & 1 & 12 \\
\hline
\end{tabular}

\section{Two Factors: Type of Variety and Language as Index of Identity in Urban vs. Non-Urban Areas}

As mentioned before, Elordieta and Romera (2020a) showed that two social factors were relevant for explaining the variation among speakers in frequency of occurrence of final falling intonational configurations in information-seeking absolute interrogatives in urban areas (Bilbao and San Sebastian). These factors were the degree of contact with Basque and the attitudes towards this language and the Basque ethnolinguistic group. That study found that a close degree of contact with Basque and a positive attitude towards this language and the Basque ethnolinguistic group were associated with a higher percentage of occurrence of falling nuclear contours, which are typical of Basque but not typical of Castilian Spanish.

In the present study, however, no correlation between the production of descending nuclear contours and social factors was found in non-urban areas (in the small towns of Ibarra and Lekeitio). We suggest that the explanation can lie in two fundamental aspects: first, the lack of real variation among speakers in the production of falling nuclear contours, and second, as a consequence of this, the impossibility of it representing any of the ethnolinguistic groups in these areas.

Regarding the first aspect, in the non-urban towns of Lekeitio and Ibarra, there are very small differences among speakers in the production of the intonational patterns of information-seeking absolute interrogative utterances. As shown in Elordieta and Romera (2020a), in the cities of San Sebastian and Bilbao, there were more differences among speakers (there were speakers with a $63 \%$ occurrence of falling intonational patterns, and others could have up to $100 \%$ ). However, in the case of Ibarra and Lekeitio, the variation was minimal. The production of falling interrogatives ranged between $85 \%$ and $100 \%$ (except for one speaker, who had $79 \%$ ), and half of them had $100 \%$. Figure 6 below shows these differences between urban and non-urban populations.

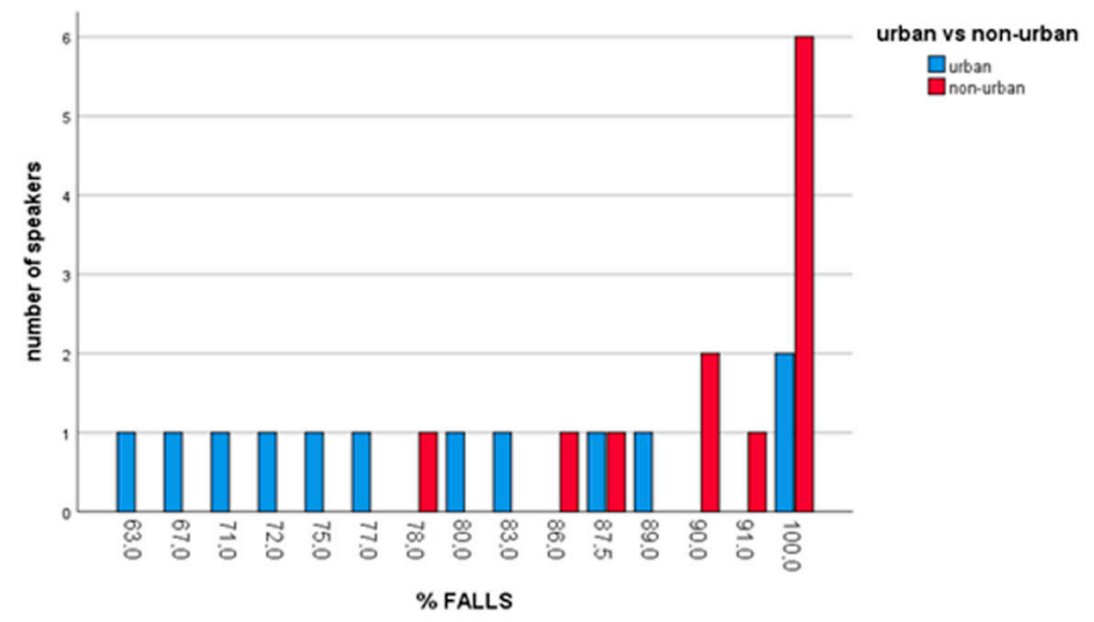

Figure 6. Percentage of interrogative sentences ending in a falling contour in urban and non-urban areas. 
This lack of variation is characteristic of a process of settlement of a linguistic change (Blas-Arroyo and Lahoz 2018). Some synchronic social factors may help us establish that falling intonational contours at the end of information-seeking absolute questions are a feature of Basque Spanish in non-urban areas, where Basque has historically been the dominant language of use.

First, the generational group that was interviewed ( $35-55$ years old) is the one that suffers the greatest social pressure to accommodate to a standard variety (Labov 2001). Information-seeking absolute interrogatives in central, standard Castilian Spanish are described to end in rising nuclear configurations, as already stated in the introductory section and in Section 2.1 of the present paper (cf. the references there). Our speakers have the opposite pattern, that is, (rising-)falling intonational contours at the end of such types of utterances. It thus seems that this feature is very stable in their variety. One could test the production of other generational groups, but as we know, younger and older generations (i.e., those between the ages of 18 and 30 and those above 60 years of age) do not have such a marked impact in the evolution of language change (Labov 2001). We therefore doubt that these groups can provoke substantial effects on the evolution of this feature.

Second, no gender differences were found in the production of falling yes/no questions. This reinforces the idea that such a feature is a settled one that does not respond to social variation.

A third argument that supports the view that falling intonational contours in absolute interrogatives are a stable feature of the variety of Spanish in non-urban towns is the historical and ongoing dominant presence of Basque. In the cities of Bilbao and San Sebastian, there is a much higher percentage of people for whom Spanish is the dominant language than in Ibarra and Lekeitio. In social terms, this means that in Bilbao and San Sebastian, the presence of the Spanish ethnolinguistic group is bigger than in Basque-dominant towns, such as Lekeitio and Ibarra. In these towns, there is little variation in the type of Spanish spoken. The variety there corresponds mainly to the vernacular variety spoken by L1 Basque speakers, the majority group in the area. The data provided by Eustat (2018) about the language used at home in 2016 reflect the overwhelming use of Spanish in the urban areas, as opposed to the dominance of Basque in the non-urban locations. As can be seen in Table 11 below, in Bilbao and in San Sebastian, the presence of Spanish at home is dominant, as opposed to Ibarra and Lekeitio, where the use of Basque at home amounts to almost $70 \%{ }^{5}$.

Table 11. Number of speakers who used Basque at home in 2016 (Eustat 2018).

\begin{tabular}{cccccc}
\hline & Basque & Spanish & Both & Other & Total \\
\hline Bilbao & 11,149 & 298,767 & 23,372 & 9784 & 343,072 \\
\hline San Sebastian & 25,509 & 126,304 & 23,479 & 5366 & 180,658 \\
\hline Ibarra & 1755 & 1633 & 618 & 129 & 4135 \\
\hline Lekeitio & 4706 & 1758 & 565 & 177 & 7206 \\
\hline
\end{tabular}

The variety of Spanish spoken in the Basque Country is the result of the long contact between these two languages (Elordieta and Romera 2020a). However, Spanish in urban areas is the result not only of the Spanish spoken by Basque speakers in the area, but also of the Spanish spoken by different groups who arrived in the Basque Country from other parts of Spain in the late 19th century and the 20th century (Zallo and Ayuso 2009). Rural areas, on the other hand, received less population, and Spanish speakers never outnumbered Basque speakers. Therefore, the Spanish spoken in non-urban areas is mostly the result of the variety of Spanish spoken by L1 Basque speakers, with a strong presence of Basque features. As we pointed out in Romera and Elordieta (2013), the transfer of features of one

5 The data reported here correspond to the use of Basque at home. We are aware that these data might differ from the use of Basque in other contexts. Unfortunately, only the global knowledge of Basque for populations of more than 40,000 inhabitants is available at this point (Eustat 2018), and although these data reduce the differences between the two languages, Spanish is still dominant in urban areas (Bilbao $61.18 \%$ and San Sebastian $57 \%$ for the population over 16 ). 
language to another can occur not only by direct influence, but also as an indirect process. When L1 Basque speakers communicated with the Spanish-speaking populations arriving in the area, they used a variety of Spanish with presence of features of their L1 (Basque). In order to communicate, the Spanish speakers accommodated their variety to the Spanish of the L1 Basque speakers as well, and as a result, L1 Basque Spanish became the common variety spoken by all. Consequently, linguistic features of Basque will be more consolidated in the Spanish spoken in non-urban areas due to the lesser presence of Spanish speakers.

This process is responsible for the absence of variation in the prosodic pattern of interrogatives in Lekeitio and Ibarra. The falling interrogative pattern is an almost entirely consolidated feature, which no longer differentiates ethnolinguistic groups in the area. All speakers in these towns use it indistinctly, and therefore, it is no longer a marker of a social group. Rather, it is an indexical feature of geographical location (Chambers and Trudgill 1998). This explains the absence of correlation with social factors, such as linguistic profile, gender, degree of contact, or linguistic attitudes, since the feature has become characteristic of the Spanish variety of the area. In urban areas, on the other hand, the nuclear configurations of absolute interrogatives show more variation (cf. Table 10 above), and there is a correlation with social factors. The feature is not only a geographical index, but also a marker that attaches the speaker to either the Spanish or the Basque ethnolinguistic group. Since linguistic features are capable of being perceived as representative of a social group, they also can be used as an expression of the ethnolinguistic identity of the person who uses them.

The concept of identity has been widely debated through different theoretical frameworks. However, there is more or less agreement in distinguishing an individual identity and a social or collective identity. The former refers to the individual consideration of oneself, whereas the latter entails the definition of the subject as belonging to a group (Bucholtz and Hall 2005; Spencer-Oatey 2007). We claim that social identity is involved in the explanation of our data. Following Butler (1990), Bucholtz and Hall (2005), and Spencer-Oatey (2007), among others, we consider that social identity is expressed, constructed, and shown to others through concrete ways of speaking and acting.

The identities put into play are adapted to the relationships, and the features that the individuals project of themselves are emphasized or minimized according to the context. Linguistic forms are a primary way of expressing identity. As Tejerina (1999), Echeverria (2003), and Baxok et al. (2006) point out, language is the main element on which Basque identity is built in the Basque Country. In urban areas, where the group of Basque speakers is smaller and there is a large group of Spanish speakers, the expression of linguistic features associated with Basque has a clear indexicalizing value that serves to claim Basque identity. The choice of such features has a clear differentiating function, and it is made precisely by those speakers whose attitudes towards Basque and the Basque ethnolinguistic group are more positive (Elordieta and Romera 2020a). Those who use it clearly align themselves with the Basque language and culture, and adopt it in order to be identified as Basque.

In contrast, non-urban areas share a variety of Spanish that already presents a strong presence of Basque features, and all the speakers ascribe to it regardless of their linguistic profile. Therefore, the Spanish language ceases to differentiate one group from the other. Identity-based adscription in these areas cannot be approached in the same terms as in urban areas. Basque linguistic features in Spanish have no possibility of being used as an indexicalizing element of Basque identity, and therefore, the speakers' linguistic profile, the degree of contact with Basque, and the linguistic attitudes cannot have a correlation with them. All the speakers interviewed in these areas presented a strong Basque identity, and differences of identity are probably expressed at other levels (Spanish, European, etc.) (Azurmendi and Bourhis 1998). We leave this point to further investigation in the future.

In summary, we can say that the linguistic features associated with the Basque language are essential for claiming identity in urban areas, and therefore, we find a positive relationship between the use of these and positive attitudes. On the contrary, in non-urban areas, the linguistic features of Basque do not exert an indexicalizing function of Basque identity, since all speakers use them equally. This explains their lack of correlation with the social factors analyzed in this study. 


\section{Conclusions}

In Elordieta and Romera (2020a), we found that an average of $79 \%$ of information-seeking absolute interrogatives ended in circumflex (rising-)falling intonational configurations in the varieties of Spanish spoken in the Basque cities of Bilbao and San Sebastian in northern Spain. In that study, a correlation was also revealed between the frequency of occurrence of final falling contours and two social factors: degree of contact with Basque and the attitudes towards this language and the Basque ethnolinguistic group. A close degree of contact with Basque and a positive attitude towards this language and the Basque ethnolinguistic group were associated with a higher percentage of occurrence of falling nuclear contours. The present study had the goal of continuing with our knowledge of the intonational characteristics of Basque Spanish by focusing on data from two non-urban areas in the Basque Country, the towns of Lekeitio and Ibarra. The research question was whether the diachronic and synchronic presence of vernacular varieties of Basque in these small towns may lead to different results in the frequency of occurrence of final falling intonational contours and the correlations with social factors.

Two main findings can be reported from the present study. On the one hand, a higher average frequency of final falling intonational contours at the end of information-seeking absolute interrogatives was found in the non-urban towns of Ibarra and Lekeitio compared to Bilbao and San Sebastian $(93.4 \%$ vs. $79 \%)$. The same tonal configuration as in Bilbao and San Sebastian was observed: $\mathrm{L}+\left({ }_{\mathrm{i}}\right) \mathrm{H}^{*}$ (H)L\%. On the other hand, no correlation was observed between the production of descending nuclear contours and social factors. We suggested that the explanation of these differences between urban and non-urban areas lies in the lack of real variation among speakers in the production of falling nuclear contours. The variation is minimal, ranging from $85 \%$ to $100 \%$ final falling contours. Indeed, half of the speakers had $100 \%$ final falling configurations. The generational group that was interviewed (35-55 years old) should suffer the greatest social pressure to accommodate to a standard variety (Labov 2001), but these speakers hardly produced rising final contours as in Castilian Spanish. It is hence apparent that falling intonational contours at the end of information-seeking absolute questions are a solid and well-established feature of Basque Spanish in non-urban areas. We argue that the pervasive presence of a Basque intonational feature, such as a final fall in absolute interrogatives, must be due to the historical dominance of Basque as a language of use in non-urban areas. That is, L1 Basque Spanish (heavily influenced by Basque) became the common variety in non-urban areas. In urban areas, in contrast, Spanish is the dominant language. The variety of Spanish there shows influence from Basque, but other varieties of Castilian Spanish also came to be present with the arrival of immigrants from other parts of Spain.

In urban areas, the nuclear configurations of absolute interrogatives show more variation, and there is a correlation with social factors. Linguistic features are capable of being perceived as representative of a social group, and can be used as an expression of the ethnolinguistic identity of the person who uses them, understood in social or collective terms (cf. (Butler 1990; Bucholtz and Hall 2005; Spencer-Oatey 2007), among others). Indeed, Tejerina (1999), Echeverria (2003), and Baxok et al. (2006) hold that language is the main element on which Basque identity is built in the Basque Country. That is, apart from being an indexical feature of geographical location (Chambers and Trudgill 1998), using falling or rising final configurations in information-seeking absolute questions is also a marker that associates the speaker to either the Spanish or the Basque ethnolinguistic group.

In rural or non-urban areas, on the other hand, the prevalence almost exclusively of falling ends of information-seeking yes/no questions leads to the impossibility of identifying frequency of occurrences of such contours with any of the ethnolinguistic groups in these areas. All speakers in these towns use falling contours indistinctly, and therefore, final falls in these sentences are no longer a marker of a social group. This explains the absence of correlation with social factors, such as linguistic profile, gender, degree of contact, or linguistic attitudes.

Author Contributions: Conceptualization, M.R. and G.E.; methodology, M.R. and G.E.; validation, M.R. and G.E.; formal analysis, M.R. and G.E.; investigation M.R. and G.E.; resources, M.R. and G.E.; data curation, M.R. and G.E.; writing—original draft preparation, M.R. and G.E.; writing—review and editing, M.R. and G.E.; visualization, 
M.R. and G.E.; supervision, M.R. and G.E.; project administration, M.R. and G.E.; funding acquisition, M.R. and G.E. All authors have read and agreed to the published version of the manuscript.

Funding: This work has been funded by the Ministry of Science and Innovation (grant number FFI2016-80021-P), the Basque Government (grant number IT1396-19) and the University of the Basque Country (grant number GIU18/221).

Acknowledgments: We are indebted to our speakers, without whom this work would not exist. We also wish to thank Varun DC Arrazola for help with the analysis of the data, and two anonymous reviewers for their positive and constructive comments. This paper also benefitted from valuable feedback provided by audiences at the following two conferences: Monterey Bay Applied Linguistics Symposium 2019, held at the University of California, Santa Cruz, 17 May 2019, and I ALFALito "Dinámicas lingüísticas de las situaciones de contacto", held at the Universidad Autónoma de Madrid, 28-30 October 2019.

Conflicts of Interest: The authors declare no conflict of interest.

\section{References}

Azurmendi, María-José, and Richard Y. Bourhis. 1998. Presentation of the research project "ICYLCABE-1996": Cultural and linguistic identities in the bilingual Autonomous Communities (BAC) of Spain. International Journal of Social Psychology 13: 547-58. [CrossRef]

Blas-Arroyo, José Luis, and Francisco Javier Vellón Lahoz. 2018. On the trail of grammaticalization in progress: Has el que become a compound relative pronoun in the history of Spanish prepositional relative clauses? Probus 30: 1-45. [CrossRef]

Baxok, Erramun, Pantxoa Etxegoin, Terexa Lekunberri, Iñaki Martínez de Luna, Larraitz Mendizabal, Igor Ahedo, Xabier Itzaina, and Roldán Jimeno. 2006. Euskal Nortasuna eta Kultura XXI. Mendearen Hasieran/Identidad y Cultura Vascas a Comienzos del Siglo XXI/Identité et Culture Basques au Début du XXIéme Siècle. Bilbao: Eusko Ikaskuntza.

Bucholtz, Mary, and Kira Hall. 2005. Identity and interaction: A sociocultural linguistic approach. Discourse Studies 7: 585-614. [CrossRef]

Butler, Judith. 1990. Gender Trouble. Feminism and the Subversion of Identity. London: Routledge.

Chambers, Jack K., and Peter Trudgill. 1998. Dialectology. Cambridge: Cambridge University Press.

Echeverria, Begoña. 2003. Language ideologies and practices in (en)gendering the Basque nation. Language in Society 32: 383-413. [CrossRef]

Eguskiza, Naia, Aintzane Etxebarria, and Iñaki Gaminde. 2017. Bai-ez galderak. In Bariazioa Esaldien Intonazioan. Edited by Aintzane Etxebarria and Naia Eguskiza. Bilbao: Universidad del País Vasco/Euskal Herriko Unibertsitatea, pp. 93-127.

Elordieta, Gorka. 2003. Intonation. In A Grammar of Basque. Edited by José Ignacio Hualde and Jon Ortiz de Urbina. Berlin: Mouton de Gruyter, pp. 72-112.

Elordieta, Gorka, and Jose I. Hualde. 2014. Intonation in Basque. In Prosodic Typology II: The Phonology of Intonation and Phrasing. Edited by Sun-Ah Jun. Oxford and New York: Oxford University Press, pp. 405-63.

Elordieta, Gorka, and Magdalena Romera. 2020a. The influence of social factors on the prosody of Spanish in contact with Basque. International Journal of Bilingualism. OnlineFirst. [CrossRef]

Elordieta, Gorka, and Magdalena Romera. 2020b. The intonation of information-seeking absolute interrogatives in Madrid Spanish. Estudios de Fonética Experimental 29: 195-213.

Escandell Vidal, Victoria. 1998. Politeness: A relevant issue for relevance theory. Revista Alicantina de Estudios Ingleses 11: 45-57. [CrossRef]

Escandell Vidal, Victoria. 1999. Los enunciados interrogativos: Aspectos semánticos y pragmáticos. In Gramática Descriptiva de la Lengua Española. Edited by Ignacio Bosque and Violeta Demonte. Madrid: Espasa-Calpe, pp. 3929-91.

Escandell Vidal, Victoria. 2017. Intonation and evidentiality in Spanish polar interrogatives. Language and Speech 60: 224-41. [CrossRef] [PubMed]

Estebas-Vilaplana, Eva, and Pilar Prieto. 2010. Castilian Spanish intonation. In Transcription of Intonation of the Spanish Language. Edited by Pilar Prieto and Paolo Roseano. Munich: Lincom Europa, pp. 17-48.

Eustat (Euskal Estatistika Erakundea-Instituto Vasco de Estadística). 2018. Población de la C.A. de Euskadi por el Municipio de Residencia, Según el sexo y la Lengua Hablada en Casa. Available 
online: https://www.eustat.eus/elementos/ele0014700/poblacion-de-la-ca-de-euskadi-por-el-municipio-d e-residencia-segun-el-sexo-y-la-lengua-hablada-en-casa/tbl0014755_c.html (accessed on 11 October 2020).

Eustat (Euskal Estatistika Erakundea-Instituto Vasco de Estadística). 2019. Datos Estadísticos de la Comunidad Autónoma de Euskadi. Available online: https://www.eustat.eus/elementos/ele0016700/la-poblacion-de-la-c -a-de-euskadi-alcanza-su-maximo-historico-a-1-de-enero-de-2019-con-2188/not0016799_c.html (accessed on 11 October 2020).

Face, Timothy L. 2008. The Intonation of Castilian Spanish Declaratives and Absolute Interrogatives. Munich: Lincom Europa.

Gaminde, Iñaki, Asier Romero Andonegi, Urtza Garay, and Aintzane Etxebarria. 2016. Los tonos de frontera de las oraciones interrogativas absolutas producidas por hablantes bilingües vasco-español. Estudios de Lingüística Aplicada 54: 61-79. [CrossRef]

González, Carolina, and Lara Reglero. 2021. The intonation of yes-no questions in Basque Spanish. In LanguagePatterns in Spanish and Beyond. Edited by Juan Colomina-Almiñana and Sandro Sessarego. London: Routledge. [CrossRef]

Henriksen, Nicholas, and Lorenzo García-Amaya. 2012. Transcription of intonation of Jerezano Andalusian Spanish. Estudios de Fonética Experimental 21: 109-62.

Henriksen, Nicholas, Meghan E. Armstrong, and Lorenzo García-Amaya. 2016. The intonational meaning of polar questions in Manchego Spanish spontaneous speech. In Intonational Grammar in Ibero-Romance. Edited by Meghan E. Armstrong, Nicholas Henriksen and Maria del Mar Vanrell. Amsterdam: John Benjamins Publishing Company, pp. 181-205.

Henriksen, Nicholas. 2010. Question Intonation in Manchego Peninsular Spanish. Ph.D. dissertation, Indiana University, Bloomington, Indiana.

Hualde, José Ignacio, and Pilar Prieto. 2015. Intonational variation in Spanish, European and American varieties. In Intonation in Romance. Edited by Sónia Frota and Pilar Prieto. Oxford: Oxford University Press, pp. 350-91.

Hualde, José Ignacio. 2005. The Sounds of Spanish. Cambridge: Cambridge University Press.

Kozminska, Kinga. 2019. Intonation, identity and contact-induced change among Polish-speaking migrants in the U.K. Journal of Sociolinguistics 23: 29-53. [CrossRef]

Labov, William. 2001. Principles of Linguistic Change, Volume 2: Social Factors. Hoboken: Wiley.

Navarro Tomás, Tomás. 1944. Manual de Entonación Española. Madrid: CSIC.

Poplack, Shana, and Stephen Levey. 2010. Contact-induced grammatical change: A cautionary tale. In Language and Space: An International Handbook of Linguistic Variation. Edited by Peter Auer and Jürgen Erich Schmidt. Berlin: Mouton de Gruyter, vol. I, pp. 391-419.

Quilis, Antonio. 1993. Tratado de Fonología y Fonética Españolas. Madrid: Gredos.

Robles-Puente, Sergio. 2012. Two languages, two intonations? Statements and yes/no questions in Spanish and Basque. Anuario del Seminario de Filología Vasca Julio de Urquijo: International Journal of Basque Linguistics and Philology 46: 251-62.

Romera, Magdalena, and Gorka Elordieta. 2013. Prosodic accommodation in language contact: Spanish intonation in Majorca. International Journal of the Sociology of Language 221: 127-51. [CrossRef]

Silva-Corvalán, Carmen. 2001. Sociolingüística y Pragmática del Español. Washington, DC: Georgetown University Press.

Spencer-Oatey, Helen. 2007. "Theories of identity and the analysis of face.". Journal of Pragmatics 39: 639-656. [CrossRef]

Tejerina, Benjamín. 1999. El poder de los símbolos: Identidad colectiva y movimiento etnolingüístico en el País Vasco. Revista Española de Investigaciones Sociológicas 88: 75-105. [CrossRef]

Torreira, Francisco, and Simeon Floyd. 2012. Intonational meaning: The case of Spanish yes-no questions. Paper presented at the Tone and Intonation in Europe, University of Oxford, Oxford, UK, September 6-8.

Winford, Donald. 2005. Contact-induced changes: Classification and processes. Diachronica 22: $373-427$. [CrossRef]

Winford, Donald. 2014. Social factors in contact languages. In Contact Languages. Edited by Peter Bakker and Yaron Matras. Berlin: Mouton de Gruyter, pp. 363-416. [CrossRef] 
Zallo, Ramón, and Mikel Ayuso. 2009. Conocer el País Vasco: Viaje al Interior de su Cultura, Historia, Sociedad e Instituciones. Bilbao: Servicio Central de Publicaciones del Gobierno Vasco.

Publisher's Note: MDPI stays neutral with regard to jurisdictional claims in published maps and institutional affiliations.

(C) 2020 by the authors. Licensee MDPI, Basel, Switzerland. This article is an open access article distributed under the terms and conditions of the Creative Commons Attribution (CC BY) license (http://creativecommons.org/licenses/by/4.0/). 